\title{
Renk Sembollerine Dair Sosyolojik Bir İnceleme*
}

Öz

\author{
Arş. Gör. Nuh Akçakaya \\ Selçuk Üniversitesi Edebiyat Fakültesi \\ Sosyoloji Bölümü \\ nuh.akcakaya@selcuk.edu.tr
}

$\mathrm{Bu}$ çalışmada renk sembolizmine dayalı olarak, sembollerin oluşumunu ve tarihsel arka planını ortaya koymak amacıyla genel bir değerlendirme yapılmıştır. Sembollerin oluşum süreci ve toplumsal aktörlerin sembollere atfettiği anlamlar önemli ölçüde bir toplumun tarihselliğini ortaya koymaktadır. Bu tarihsellik toplumların belirli hikâyeler üzerinden belirli organizasyonları geliştirmesinin yanında belirli anlam haritalarını oluşturmasına da hizmet etmektedir. Söz konusu anlam haritaları üzerinden birbirleriyle ortak bir bilinç üzerinden iletişime geçen bireyler, mekanik olarak bir araya gelemeyecek zihinlerini ortak imge ve anlam üzerinden bir araya getirmektedirler. Bireyler açısından bu imgeler ve anlamlar zaman ve mekân içerisinde sürekli olarak bir değişim geçirseler de kendisini belirli tarihsel arka plana dayandırabilen anlamlar, kısa vadeli oluşmuş anlamlara göre daha yavaş değişmektedirler. Renk sembollerinin anlamları da bireylerin o anlamlara yapacă̆ müdahale ve yorumlar nispetinde değişim göstermektedir. Renk anlamı ve birey arasındaki ilişki, yapı-fail ilişkisine benzer olarak bir diyalektik süreci içermektedir. Böylece bireyler oluşturmuş olduğu renk anlamlarından etkilenebilmekte söz konusu renkleri gündelik yaşamlarının bir unsuru olarak kullanabilmektedir.

Anahtar Kelimeler: Renklerin sosyolojisi, sembollerin oluşumu, renk anlamları.

\section{A Sociological Study on the Color Symbols}

\section{Abstract}

In this study, a general evaluation has been made with the aim of revealing the formation of the color symbolisim and the historical background of these symbols. The formation process of symbols and the meanings that social actors attribute to symbols reveals the historicity of a society to a considerable extent. This historicity serves not only to develop specific organizations through specific stories, but also to create specific meaning maps. Individuals who communicate with each other through a common consciousness through the aforementioned semantic maps, bring together the minds that can not come together mechanically through common image and meaning. In terms of individuals, even if these imagery and meanings undergo constant change in time and space, meanings based on a particular historical background are changing more slowly than short-term meanings. The meanings of the color symbols vary according to the interventions and interpretations that individuals will make on those meanings. The relationship between color meaning and the individual involves a dialectic process similar to the agency-structure relationship. This is because individuals can be influenced by the color meanings they have formed and at the same time they can use the colors as an element of their daily life.

Keywords: Sociology of colors, formation of symbols, color meanings.

\footnotetext{
* Bu makale, Prof. Dr. Köksal ALVER danışmanlığında tamamlanan Renklerin Sosyolojisi: Renklerin Toplumsal Mahiyeti Üzerine Bir İnceleme başlıklı Yüksek Lisans tezinden üretilmiştir. 


\section{GİRIŞ}

İnsanoğlunun iletişim ve etkileşimi tesis etmek adına geliştirdiği yöntemler ve enstrümanlar arasında semboller önemli bir alanı kapsamaktadır. Semboller hem iki ya da daha fazla insanın anlık iletişimini tesis edebilecek hem de insanın belirli anlatılar ile bağlantı kurmasını temin edebilecek özelliklere sahiptirler. Bu noktada semboller, mekanik olarak bir araya gelemeyecek insan zihinlerini bir araya getirebilecek yapısal hüviyete sahip olmanın yanında; farklı toplumların anlam haritasını ve halesini ortaya koymak açısından özellikle toplumbilimsel düşünceye önemli ipuçları sağlamaktadırlar. Bireylerin sembol olarak yapılandırdığı jestler, mimikler, sesler, davranış kalıpları, nesneler veyahut anlatılar; büyük oranda insanın bir arada yaşamasının temel gereklilikleri mahiyetindedir. Bunun yanında her geçen gün yeni bir sembolün gündelik yaşama dâhil oluşu; sanat, edebiyat ve medeniyet kalıplarının sürekli olarak yeni iletişim ve etkileşim enstrümanları üretmesi; sadece bugün değil, insanlık tarihi boyunca devinim halinde görülen bir husustur.

Bireylerin üretmiş olduğu sembol anlamları ve biçimleri; teknik, mistik veya teolojik bilginin muhteviyatına göre sürekli değişmektedir. Ancak izlerinin kadim medeniyetlere kadar sürülebildiği kimi semboller, önemli ölçüde insan davranışını biçimlendirme özelliğini koruyabilmiş vaziyettedir. Anlamsal değişimin kaçınılmaz olarak gerçekleştiği bu semboller, sadece insanı etkilemek ve onu biçimlendirmek noktasında istisnai olarak pek az değişmiştir. İnsanoğlunun inşa ettiği en iptidai sembollerden en karmaşık yazılımlara kadar; birçok anlam atfetme etkinliği, onun iletişim ve etkileşiminin temel materyalleri olmasının yanında, insanoğlunun şeyleştirdiği ve karşısında edilgenleştiği unsurlar olarak da karşımıza çıkmaktadır. Birer sembol olarak görülebilecek renklerin de iletişim ve etkileşim enstrümanı biçiminde kullanıldığı uzun zamanlardan beri bilinmektedir. Sadece günümüzde değil tarihsel süreç içerisinde de renklerin, bir dizi normatif tutum ve davranış örüntülerini meydana getirebildiği, kimi anlatıların temsilcisi mesabesinde olabildiği, hem toplumsal hem de bireysel düzeyde bir çeşit kim-lik unsuru teşkil edebildiği bilinmektedir.

$\mathrm{Bu}$ çalışmada renk sembollerinin insan eylemine olan tesiri ile beraber oluşturmuş olduğu ortak duygu ve imgelem incelenecektir. Bu minvalde özellikle renk sembollerinin ilk etapta nasıl ortaya çıkmış olabileceğine, söz konusu sembollerin zaman içerisinde büründüğü anlamsal değişimlere, sembollere karşı yöneltilen bireysel tavırların nasıl ahlaki bir form üzerinden iletildiğine, bireylerin mevcut toplumsal zeminde sembolleri değiştirmeye yönelik geliştirmiş olduğu tutum ve davranışlara dair bir tartışma yürütülecektir. Bununla beraber renk sembollerinin toplumsal hayat içerisinde nasıl var olduğu ve idare edildiği üzerine sosyolojik bir anlayış geliştirilmeye çalışılacaktır. Bu anlayışın geliştirilmesi ve renk fenomeninin somut bir zemin üzerinden değerlendirilmesi için bir dizi örneklerin verilmesi gerekmektedir. Bu örnekler, renklerin sosyolojik yönünün ortaya konması açısından önem teşkil etmekle beraber, renklerin sosyal teorinin daha önceki sayıtlıları üzerinden incelenmesini de sağlayacaktır.

\section{SEMBOL ANLAMLARININ OLUŞMASI VE RENK HİKÂYECİLIĞİ}

Renklerin sosyolojik olarak önemine değinmek gerektiğinde ilk başta onların ürettiği sembolizasyona değinmek gerekmektedir. Çünkü sosyal teoride sembollere, etkileşim ve anlamı inşa eden unsurlar olarak görülebilecek kadar fazla değer verilmektedir (Ritzer 2013: 230). Semboller hitap ettiği kitle için etik bir değer taşır ve kitlenin vicdanına tesir edebilir. Çünkü semboller birer düzen unsurudur ve sembollerin ihlal edilmesi, düzenin ihlal edilmesi anlamına gelebilir. Her sembol, bir hikâyenin öğretisini taşımakla ve bir mesaj 
vermekle yükümlüdür. Bu durum Türkler (Toker 2009), Araplar (Al-Adaileh 2012) ve diğer bütün toplumlar için böyle görülebilir. Hikâyeleri ölümsüzleştirmek, hatırlamak, kullanmak adına icat ya da icra edilen semboller; toplumsal aktörleri daima zinde tutmak gibi bir işlev görebilmektedirler. Bunun yanında söz konusu semboller hitap ettiği kitle arasında bir kolektivite üretebilmektedirler. O kolektivitenin bir nesnesi olan 'birey' kendi yorumların mümkün olduğu ölçüde sınırlı tutarak, söz konusu 'şeyleşmiş sembolün' değişim ve dönüşümünü de yavaşlatmış olur. Ancak bununla beraber insan kendisine dayatılan sembolleri 'kabul etmek zorunda da değildir' (Ritzer 2013: 231). İnsanın kabul ettiği sembollerin ürettiği kolektivite, kendisini tinsel şeylerden çok bir hikâyeye dayandırdığı için realist-gerçekçi karakterde bir kolektivite üretir. Bunun sebebi, toplumsal aktör için hikâyesi olan şeyin gerçek olma ihtimalinin yüksek olmasıdır. Bu hikâyeler; yaşanmış olsun ya da olmasın, yaşanmamış olsa bile yaşanması muhtemeldir, kendi şartları içerisinde rasyoneldir. Renkler bu noktada sembol üreten, hikâyesi olan ve bu hikâye ile sembol üzerinden tekrar bir kolektivite üreten unsurlar olarak görülebilir.

Rengin gündelik hayatta insanın duygu, düşünce ve davranışına; iki ayrı cepheden tesir ettiği görülmektedir. Bunlardan birisi 'kavramsal çağrışım ya da imgesel boyut' diğeri ise 'sembolik renk' değeridir. Kavramsal-imgesel çağrışım noktasında renk kelimelerinin anlamı, farklı kültürlerde "negatif ve pozitif anlamları" içeren imgeleri kapsamlı olarak açığa çıarır (Yu 2014: 49). İmgesel durumun ya da rengin kavramsal çağrışımının genellikle 'estetik değerlerle' mücehhez olduğu görülmektedir. Öte yandan sembolik renk değerlerine karşı yaklaşımın altında ise daha çok etik değerlerin söz konusu olduğu gözlemlenmektedir. İmgesel ya da kavramsal değerlendirmeler, güzel-çirkin değerlendirmesine tabi tutulabilirken; sembolik renk değerlendirmelerinde iyi-kötü yaklaşımlarının ön plana çıktığı görülmektedir.

Estetik konusunda her ne kadar Amsteus ve ekibi (2015: 34) renklerin tercih edilmesini estetik bir durumun ötesinde, 'bağlamsal ve öğrenmeyle' ilişkili bir durum olarak görse de burada tamamen 'öznenin tasarrufunda' olan bir beğeninin de olabileceği aşikârdır. Bu beğeniyi tek başına öğrenmeyle açıklamak hem bilimsel hem de felsefi açıdan yetersiz görünmektedir. ${ }^{1}$ Zira beğeni için, onu besleyen kişisel estetik algılarına değinmek gerekmektedir. Ancak tersten düşünüldüğünde, bu beğeni ya da estetiğin, öğrenme sürecinden müstakil bir şekilde gerçekleştiğini iddia etmek de indirgemeci bir tutum olabilir. Estetik yargılarının kendisinde bir bağlamsallık, öğrenme ya da bilinçlilik hali söz konusu olsa da Kant'ın estetik yargılarının bir idraksizlik -noncognitivism- durumu olduğu noktasında 1srar etmesi (Shaviro 2009: 13) her şeye rağmen yersiz bir tutum değildir. Çünkü 'güzellik ya da çirkinlik' yargısı öğrenme süreçleriyle ilişki içerisinde olan ama aynı zamanda sistematize kalıpların dışına çıkan çok boyutlu bir fenomen olma özelliği taşımaktadır.

Renklerin güzel-çirkin ya da iyi-kötü olarak addedilebilmesi şüphesiz etik ve estetik alanlarını ilgilendiren hususların göz önünde bulundurulmasını gerektirecektir. Bu estetik

\footnotetext{
${ }^{1}$ Felsefeciler estetik ve beğeni edimlerinin toplum tarafından mı ögretildiği yoksa beğenilen şeyin doğasıyla ilgili mi olduğu noktasında farklı görüşler öne sürerler. Mesela bir kitle tarafından dinlenilen orkestranın sunduğu estetik, kimilerine göre müziği sunan ve onu dinleyen arasında ortak bir algıdan ya da öğretilmiş bir hazdan dolayı güzel müzik olarak algılanabilir. Söz gelimi Luciano Pavarotti'nin yaptığı müzik Konyalı bir müzikseverle aynı estetik değerleri -belki de imgeleri- paylaşmadığı için beğenilmeyebilir. Ama öte yandan kimi Felsefecilere göre fenomenlerin doğası onun güzelliğine ve çirkinliğine karar verdirebilir. Mesela aynı Pavarotti güzel müzik yaptığından dolayı ortak imge düzleminde çok az bir zemin paylaşmalarına rağmen, bir Adanalı tarafından kulağa hoş geldiği için beğenilebilir. Bu beğeniyi ise öğrenmeyle açıklamak yetersiz görünmektedir.

SEFAD, 2018 (39): 373-388
} 
algıları 'her nasıl gerçekleşirse gerçekleşsin' son kertede renklere karşı tutumları belirleyebilmektedir. Ancak burada, renklerin sembollerle girdiği ilişki veya rengin sembolleşmesi durumu güzellik-çirkinlikle yani estetikle tebarüz eden bir durum değildir. İnsan tarafından sembolik bir rengin, etik yargılarla donatılmış bir muamele gördüğü tarihi çağlar boyunca neredeyse sabittir. Mesela Hiristiyanlarda beyaz, tüm renklerin en temizi olduğu için inançta saflığın bir göstergesidir (Yu 2014: 50). Beyazın bir saflık ve arılık hikayesinin olması onu sembolik bir unsur haline getirmektedir. Ancak bu durumun imgeler üzerine etkisinin olmadığını söylemek de yanlış olur. Beyaz bu noktada hem imgesel anlamda hem de sembolik anlamda iyi olanının vazgeçilmez temsilcisidir. Beyaz ve Hırisyanlık arasındaki bağlantı Hz. İsa'nın öğretisiyle bağdaştırılmaktadır (Pastoureau 2005: 43). Bu hikayeye inanmak ve 'beyaza hak ettiği itibarı vermek' ise, dindar bir Hrıstiyan için estetik yargılarının ötesinde 'ahlaki bir yükümlülük' olarak görülebilmektedir. Bu durumun aynısı şüphesiz İslam ve yeşil irtibatı için de söz konusu olabilir.

Her sembol ve dolayısıyla her 'sembolik renk' bir hikayenin ürünü olarak görülebilir. Bu hikayenin gerçek olması veya detaylarının genel geçer olması gibi bir zaruret söz konusu olmamakla beraber, sembolik renk hikayelerinin içeriği değişebilir ve bir tuttarlılığının olmadığı da görülebilir. Mesela yine Hıristiyanlık anlatılarından bazılarında Hz. İsa'nın çocuk yaşta kumaş boyacılığı yaptığına dair bir hikâye vardır. Hz. İsa'nın boyacı çırağı olarak çalıştı̆̆ bu dönemde, Hıristiyan menkıbelerinde, renklerle ilgili yanlış bir eylemde bulunduğu rivayet edilir. Bu hikâye farklı dönemlerde kötü olarak algılanan renkler üzerinden sembolize edilmiştir. Farklı zamanların imgeleriyle sembolleştirilen bu hikâyenin kısmen konusunu vermek gerekirse; Kumaş boyacısı çıraklığı yapan Hz. İsa'nın çocukken farklı renklerde boyanması gereken kumaşları -mesela iki ayrı kumaştan birisi sarı, birisi yeşile boyanmalıyken- muzipliğine kumaşları karıştırıp aynı renge boyamasıdır. Hz. İsa'nın şaka olsun diye yapmış olduğu bu hareket Hıristiyan teolojisinde, İsa'nın bir kusuru olarak addedilmeye meyyal bir durumu teşkil etmiştir. Ancak ne var ki hikâyelerin yazıldığ 1 farklı farklı dönemlerde bu 'kötü' durumu anlatmak için İsa'nın aynı renk olarak boyadığı iddia edilen renk, salt mavi ya da salt siyah olarak betimlenmiştir. "İsa kumaşları mavi olarak boyadı" iddiasında olan hikâyelerin yazıldığı dönemde; en sevilmeyen -lanetli- renk mavi olarak görülürken, "siyah olarak boyadı" diyen hikâyelerin yazıldığı dönemde bu olumsuz anlamı çağrıştıran rengin siyah olduğu bilinmektedir ve bu durum sarı içinde geçerlidir (Pastoureau 2012: 101-103). Hz. İsa'nın kötü bir iş yaptığını ve kötü işler için kötü enstrümanların kullanıldığını vurgulamak isteyen metin yazıcılar, enstrümanları (renk) çağın en kötü olanları arasından seçmek gibi bir tutum gütmüşlerdir.

Burada sanat eyleme biçiminin şekli toplumsal imgeye ve sembolizasyona göre değişebilmektedir. Hâlbuki hikâye aynı hikâyedir. Ve her yazılışında şayet yazar yeni verilere ulaşamadıysa -ki bu çok zayıf bir ihtimal gibi görünüyor- muhtemelen aynı kaynaklar üzerinden yazılma yoluna gidilmiştir. Ancak sanatçının, okuyucuya vermeye çalıştığı şeyi sanatçı, çoğu zaman okuyucunun imgelemiyle uyuşturmak zorunda olduğunu bildiğinden ötürü, bu yolu tercih ettiği görülmektedir. Yani buradan anlaşılacağı üzere belirli etik-estetik algılarının -sanatçının ya da toplumun algısı- belirli hikâyelere belirli yakıştırmaların yapılmasını zaruri kılabildiği görülmektedir. Bir yandan sevilmeyen renk kötü hikâyelerle ilişkilendirilirken, diğer yandan sevilmeyen hikâyeler kötü renklerle ilişkilendirilebilmektedir. Bu durum, hikâyesi olan bir sembolik rengin, insan imgelemini nasıl etkilediğine örnek olması bakımından, önemli bir örnekleme olarak karşımıza çıkmaktadır. 
Toplumsal bir fenomen hükmünde olan renkler, doğasında ve kimyasında hiçbir değişiklik olmamasına rağmen kimi zaman kötü hikâyeleri kimi zamanda iyi hikâyeleri temsil etme iradesini taşımaktadır. Bu temsiliyet ise şüphesiz sembolik ya da imgesel düzeyde cereyan etmektedir. Toplumsal temsilleri-sembolleri üretenler, Becker'e göre (2016: 28-32) sıradan insanların yanında sanatçı, edebiyatçı ve belki de bir fotoğrafçı olabilir. Bu üretme tarzı ve üslubu şüphesiz sembolü üreten kişinin kendi değer yargılarıyla ve üretilen sembolün toplumsal hafızadaki konumuna göre şekillenmektedir. Sembollerle ilişki içerisinde olan hikâyelendirme temayülleri, rengin gündelik hayatta kullanımını oldukça fazla etkileyebilmektedir. Söz gelimi 20. yy boyunca çevreci hareketler yeşil ile irtibatlandırılırken, kırmızı özel olarak komünist partilerle ilişkilendirildi (Yu 2014: 50). Bu ilişkilendirme, söz konusu ideolojilerin müntesiplerini bu renkleri kullanma noktasında günümüzde bile fazlaca etkilemektedir. Bu iki siyasal hareketin belirli renkler üzerinden söylem geliştirmesi, hatta kendi söyleminden ziyade öteki tarafından yapılan etiketlemeler kızıl komünist, yeşil baş [green head] gibi- onun hem kendi siyasal ideolojisini belirli bir renkle kimliklendirmesine hem de karşı tarafın, onun kendisini tanımlamasına neden olabilmektedir. Bu durum ise kimlik cüzdanı, soy, ırk gibi tanımlayıcı unsurların bireye kattığı duyguların benzerini kattığı için kişi, kimi zaman bunu bir ihtiyaç olarak görebilmektedir. Kendisini sarı kanarya ya da kara kartal olarak görmek, kartallığın yanında karalık'la da övünmek, yeri geldiğinde karayı sarıdan daha üstün algılamak; kendini tanımlamak içgüdüsünün renklerle olan ilişkisini ortaya koymaktadır.

Semboller üzerine çalışan Jung, bazı sembollerin sürekli ve evrensel bir dile sahip olduğunu söyleyerek, belirli formların kültürler arasında yüzyıllar boyunca benzer anlamlarla anılabileceğini ifade eder. Bu durumu doğal iç psikolojik güçlerin ifadesi olarak görür (Yu 2014). Ancak Junk'un yaptığı sembol betimlemesi bazı durumları açıklamak için yetersiz görünmektedir. Evrensel bir sembolizm algısı diye bir şeyin söz konusu olması için evrensel bir hikâyenin ya da net bir renk doğasının söz konusu olması gerekmektedir. Oysa rengin ne olduğuna dair 'genel geçer bir görüş' bile söz konusu değildir (Wittgenstein 2007: 36). Mesela beyaz, gerek optiksel özellikleri bakımından gerekse hikâye ve anlatılarda çoğu zaman 'iyinin' temsilcisi olması bakımından evrensel olarak saflık ve temizliğin göstergesi olarak düşünülebilir. Beyazın dünya toplumlarının çoğunda genel geçer olarak "iyi" görülmesine rağmen -mesela beyaz bayrağın evrensel olarak barış göstergesi olması gibibunun bile bir istisnası vardır. Buna örnek olarak Hindistan'da "sati" geleneğiyle müsemma olan dul kadınlar verilebilir. Bu geleneğe göre dul kadınlar beyaz giymek zorundadırlar (Albayrak 2008: 24). Dul kadınların kast sistemi içinde 'en aşağı' insanlardan birisi olarak algılanmaları beyazın ve dolayısıyla temsil ettiği değerin olumsuz kimliğini göz önüne koymaktadır. Burada beyaz 'lanetin' rengi olarak görülebilir. Hindistan'daki beyaz ve dulluk terkipleri, "beyaz evrensel olarak iyinin temsilcisidir" tezini tek başına tartışmaya açabilecek niteliktedir. Ancak yine aynı Hindistan'da gelinlik renklerinin de beyaz olarak tercih edilebilmesi o rengin aslında kimi zaman olumlu bir hikâyenin nesnesi olabileceği anlamını da taşıyabilmektedir. Hindistan'daki beyaz algısı tıpkı Avrupa'daki siyah algısı gibidir. Avrupa'da siyah, birçok farklı periyot içerisinde farklı anlamları ya da eş zamanlı olarak olumlu ve olumsuz anlamları birlikte üstlenebilmiştir (Pastoureau 2012).

Beyaz ve siyahın yanında mavi renk için de bir evrensellik söz konusu olmamaktadır. Mavi hem tarihsel periyotlar arasında hem de aynı toplumun farklı katmanları arasında farklı anlamlara sahip olagelmektedir. Yine bu renk de genel geçer bir evrensel algiyı temsil etme iradesinden yoksun görünmektedir (Pastoureau 2005). Mavi, ancak ve ancak özel 
olarak ona yüklenen hikâyeye göre olumlu ya da olumsuz bir sembolizma üretebilmektedir. Nihai olarak birçok rengin, eğer bir sembolik temsiliyet taşıyorsa, bu sembolik değerini bir hikâyeye borçlu olduğu görülmektedir. Özellikle bazı psikologların sıklıkla düştüğü yanılgı olan determinist yaklaşım, birçok renk için doğrulanamayacak bir yaklaşımı teşkil etmektedir. Ancak buna karşın sınırlı ölçekler ve örneklem üzerinden yapılan çalışmaların kendi içerisinde doğruluğunun kabul edilebilecek düzeyde olduğu görülmektedir.

\section{RENK SEMBOLIZMININ ETIKLE İLIŞKİSI}

Semboller derinlikli ve karmaşık bir yapıyı ihtiva etmektedirler. Bu noktada onları anlamak ve anlatmak her zaman mümkün olmayabilir. Mesela, Hilal İslam'ı, Haç Hıristiyanlığı temsil etmektedir. Hilalin oruç ibadetinin zamanını belirlediğinden dolayı İslam'ın bir sembolü olduğunu iddia edenler, namazın vaktini belirleyen güneşin ne için İslam'ın sembolü olamadığını muhtemelen açıklayamayacaklardır (Aydın 2013: 376-377). Bunun nedeni şüphesiz sembolün hitap ettiği kitle için hikayesinde bir gerçeklik ya da rasyonalite aranmamasıdır. Esasında kimi aktörlere göre hikayenin içeriğinden çok, hikayenin 'var olmass' bile bir rasyonalite olarak görülebilmektedir. Sembolün hikayesi karışık, çelişkili, anlamsız olabilir veya hikaye hiç olmayabilir. Ama söz konusu sembol herhangi bir unsur ile ilişkilendiriliyorsa; bu ideoloji, din, tanrı, efsane, mit, kültür ya da birilerinin saygı duyduğu, nefret ettiği herhangi bir şey olabilir; ona uymak, sembole saygı göstermek, onu işlevi bağlamında kullanmak ahlaki bir sorumluluk olarak görülebilmektedir. Çünkü sembolün ihlali, dayandığı öğretinin ihlali anlamına gelebilmektedir.

Sembol hikayelerinin dış dünyada kaçınılmaz olarak gerçeğe tekabül edeceğini varsaymak felsefi realizmde de olduğu gibi 'sembolleri uyumsuz olarak görmeye' sebep olabilir (Ritzer 2013: 230). Sonuç olarak semboller, hitap ettiği kitle için diş dünyadaki gerçekliğinin sorgulanmasından ziyade ahlak bağlamında bir muamele görmektedirler. Baudrillard'ın (2014: 4) da ifade ettiği gibi sembollerin yanında renkler "kendisine yüklenen anlama boyun eğmek durumunda kalmakta"dır. Bu durum toplumumuzda yaşça büyük kimselerin karşısında bacak bacak üstüne atmaya benzetilebilir. Bacak bacak üstüne atmak saygısızlık olarak addedilebilirken, kolları birbirine bağlamak -kol kol üstüne atmakherhangi bir ahlaki öğretinin ilgi alanına girmemektedir. Hatta birinin karşısında kollardan ziyade elleri bağlamak -belki de el pençe divan durmak- bir saygı göstergesi olarak algılanabilmektedir. Ancak hiçbir toplumsal aktör, el el üstüne atmak ile ayak ayak üstüne atmak arasındaki bağlam farkını sorma niyetinde olmaz. Burada semboller gibi jestler de kendisine yüklenen anlama boyun eğmek mecburiyetindedir. Çünkü sembollerin yapısından ziyade işlevi önplana çıkmaktadır. Bu durumda görülen odur ki ahlaki vurguların dayandığı gerçeklikten ziyade onun sorgusuz sualsiz yerine getirilmesi toplumsal aktörlerin asıl odak noktasını teşkil etmektedir. Ancak her halükarda semboller insanların etkileşim kurmasında önemli unsurlar olarak görülmektedir (Ritzer 2013: 220). Bu etkileşimin enstrümanları, çeşitli toplumsal formasyonun birbiriyle ahenk içerisinde var olmasina neden olabilmektedir.

Foucault; farklı dönemlerde, aynı kurallara farklı kişilerin, farklı boyun eğme biçiminin olabileceğini göstermeye çalışarak (Davidson 2002: 112) ahlak yasalarıla özne arasındaki değişkenlik arz eden ilişki biçimine işaret etmektedir. Şüphesiz Faucault'nun (2007) birçok kez kabul ettiği üzere, bu ahlak yasalarının anlatı ve tarih ile yakından bir ilişkisi söz konusudur. Anlatı ve tarihin şahitleri olma hüviyetine sahip semboller, bu 
minvalde ahlaki kaideler gibi değişime ve dönüşüme uğramaktadırlar. Ahlakın ya da normatif yapının değişkenlik arz etmesi, ahlak ve normatif yapının unsurlarına karşı yapılan muamelenin de değişkenlik arz edeceği anlamını taşımaktadır. Anlatıların birer elementi konumunda olabilen 'sembolik renklerin' ayn değişim sürecine dahil olabildiği görülmektedir. Bu değişimin dinamizmini bilmek ve hangi biçimle ilişkili olursa olsun sembolik rengin 'ahlaki boyutuna' dikkat çekmek, herhangi bir sosyolojik çözümleme için hayati bir unsur olarak karşımıza çıkmaktadır. Weber'in (2008: 365-458) Kapitalizm ve Protestan ahlakı arasında kurduğu bağlantı gibi Pastoureau'da (2005: 124) Batıda kitlesel üretimde renklerin tercih edilmesini ya da edilmemesini 'Protestan ahlakına bağlı olan' ahlaksal ve toplumsal düşüncenin eşlik ettiğini ifade etmektedir. Bu ahlak eksenli üretme biçiminin, kendisini ilk olarak arabaların, daktiloların, dolmakalemlerin üzerinde siyah-gribeyaz-mavi olarak gösterdiği görülmektedir. Bu renkler Protestanların genel olarak benimsediği renkleri oluşturmaktadır. O zamanlarda kimya ve boyama tekniklerinin çok farklı renkleri elde edebilme yetisine bilgisel olarak sahip olduğu bilinmektedir. Fakat buna rağmen Protestan etiği, burada kitle üretiminin şeklini derin ve yavaş bir şekilde sınırlı renkler üzerinden etkilemiştir.

Renk ve etik arasındaki ilişkisellik, bir yerden kamusal alanda görünür halde olan nesnelerin etik değerlerin öngördüğü şekilde boyanması olurken; diğer yandan var olan boyanmış eşyanın rengine karşı olumlu ya da olumsuz bir yaklaşım şeklinde olabilmektedir. Yani eşyayı üretirken ve tüketirken onun rengine karşı takınılan tavırda bir ahlak mülahazası söz konusu olmaktadır. Örneğin 1200'lü yılların sonlarında Avrupa'nın hemen her yerinde renklendirme işlemiyle ilgili belirli 'yasalar ve yasaklamalar' koyulmuştu. $\mathrm{Bu}$ yasakoyuculuk tavrı, temelde üç nedene dayanıyordu. İlk neden; pahalı ve ihraç malı olan 'boya maddelerinin' ülke ekonomisine zarar vermesiydi ve boyacılığın-boyanın üretime değil tüketime dayalı bir yatırım olarak görülmesiydi. Bunun yanında gösteriş ve abartının Hıristiyanlık öğretisiyle uyuşmadığının düşünülmesi; yasalarla 'boyanmanın-boyamanın' yasaklanmasının bir diğer nedeniydi. Son olarak yaş, cinsiyet, statü, saygınlık gibi toplumsal hususiyetlere sahip olanların ayrı ayrı ya da kendi içerisinde belirli renkleri giymesi ve bu minvalde toplumsal katmanların belli olması, keskin toplumsal tabakaların oluşmasına neden oluyordu ve bu durum tabakalar arasında geçişleri engelliyordu (Pastoureau 2012: 112). Bu sebepler ve sorun alanları için renk konusunda devlet eliyle, öznenin ideolojik nedenlerle toplumsal ayrımcllığa maruz bırakılamayacağı yasalar tesis edilmeye çalışılıyordu. Esasında bu duruma bakıldığında rengin sadece sembolik düzeyde değil, imgesel kullanım düzeyinde de bir ahlaki ilişkinin söz konusu olabildiği görülmektedir.

Renk ve etik ilişkisi genelde sembolizma üzerinden sağlam bir ilişki ağı kursa da gündelik yaşamda aktörlerin gayrı ihtiyari bir şekilde kullandığı eşya üzerinde de bir etik değerlendirmesi yapılabilir. Bu renk etiğinin beslendiği tarihsel ve mitsel hususlar rengi üretenler ve onu tüketenler nezdinde kayda değer bir bilinçlilik hali inşa etmektedir. Örneğin, Hıristiyan toplumlarda renkler gündelik yaşamın unsurlarını baskın bir şekilde belirleyebilmekteydi (Pastoureau 2012: 70). Bu gibi durumlar sanattan siyasete; ekonomiden dine kadar birçok alanda kendisini göstermektedir. Gündelik hayatta renk etiğinin herhangi bir sembolik renge yapılacak olan aksi atıflarda daha fazla gün yüzüne çıktığ 1 görülebilmektedir. Türkiye'de bu durumu gözlemlemek isteyen birisinin, Türk bayrağındaki kırmızı renge yapacağı olumsuz bir atfı ya da saldırganlığı ve buna mukabil göreceği muamele, özellikle etik ve sembolik renk ilişkisini göz önüne sermesi açısından önemli bir 
örnekleme biçimi olabilir. Veyahut faraza, 'pembe rengin' erkeksiliğine yapılacak olan vurgu da yine temelde ahlaki argümanlarla muhalefet biçimlerini doğurabilecektir.

\section{SEMBOLIKK RENGINN ÜRETTIĞİ REALISTT KOLEKTIVITTE}

Burada sembolik renklerin ürettiği kolektif bilinç kavramına geçmeden önce kanaat odur ki realist kolektivite kavramıla anlatılmaya çalışılan şeyin ifade edilmesi gerekmektedir. Durkheim'in geliştirmiş olduğu kolektif bilinç kavramında (Ritzer-Stepnısky 2014: 81) üretilen bilincin yapısına çok az dikkat çekilmektedir. Durkheim, söz konusu bilincin toplumsal aktörleri nasıl etkildiği üzerine birçok araştırma ve değerlendirme yapmasına rağmen, bu bilincin toplumsal değişim karşısındaki mukavemetine ve bilinci oluşturan unsurlara çok az değinmektedir. "Anomi" ya da "toplumsal akımlar" kavramlarıyla ile söz konusu bilincin dejenerasyonuna/değişimine işaret etse de aynı toplumsal yapının içerisinde normsuzluğun hangi unsurlar üzerinde daha çok etkili olabileceğini açıklığa kavuşturmakla beraber, kendisinin "kolektif temsiller" olarak adlandırdığı temsillerin anlamlandırılmasının, duygu ile mi yoksa rasyonel sebeplerle mi gerçekleştirildiğini açıklığa kavuşturmadığı görülmektedir. Söz gelimi dinsel alanın ürettiği kolektif bilinç ile siyasal alanın ürettiği kolektif bilincin ve bunların temsillerinin, anomik taarruzlar karşısında mukavemetini değerlendirmediği bilinmektedir. Genel olarak Durhkheim, "kolektif bilinç" kavramıla toplumsal yaşamın bütün pratik bilgisinin oluşturduğu bir ortaklık alanına işaret etmiştir. Fakat bu başlık altında Durkheim'dan farklı olarak, kolektif bilinç kavramının, her sosyolojik kurum üzerinden ayrı ayrı değerlendirilebilecek kadar derin ve karmaşık bir kavram olduğu varsayımı ile hareket edilecektir.

Trafik kurallarından aile içi ilişkilerin düzenine kadar hayatın hemen her alanında bir birlikteliğin söz konusu olması, bu birlikteliğin kimi semboller üzerinden sürekli yeniden üretilmesi, sembollerin kimi zaman değişim karşısında bir kısım diğer semboller nispetinde daha dirençli, saldırgan ve muhafazakar olabilmesi; şüphesiz kişilerarası ortaklık kurma işlevi gören 'temsilleri, sembolleri ve bilinçlilik hallerini' birbirinden farklı kılmaktadır. Bu noktada kimi sembolik unsurların ürettiği ortaklık alanı ve toplumsal aktörlere söz geçirebilme marifeti de referans aldığı epistemolojiye göre değişkenlik arz etmektedir. Yani kısaca, 'sembole uyma durumunun' kişilerarası bir değişkenliğinin olduğu görülmektedir (Reisman 2016: 277). Haliyle bu değişkenlik kolektif bilinç unsurlarının ya da süreçlerinin farklı farklı üzerinde durulmasını gerektirmektedir. Burada ifade edilen realist kolektivite tam olarak; bir toplumun değişmesine mümkün ölçüde müsaade etmediği, kendisini gerçekçi [realist] köklerle izhar eden, 'şeyleşmiş bilinçlilik halleri' olarak okunabilir. Bundan dolayı realist kolektivitenin realist temsiller/semboller üretebildiği ya da bunlar üzerinden şekillenebildiği diyalektik bir sürecin olduğu görülmektedir. Toplumsal sürekliliğin istikrarı için toplumsal aktör, söz konusu şeyleşmiş bilinci ve onun temsillerini hayati görüp, onu genel olarak muhafaza etme tutumu güdebilmektedir. Bu noktada şeyleşmiş bilinçlilik hallerinin ve temsillerin ürettiği realist kolektivite, kendisini diğer gerçekçi olmayan kolektif temsillere göre daha sağlam bir epistemoloji üzerine oturtabilmektedir.

Renkler için söylemek gerektiğinde, bayrak renklerinin ve futbol takımı renklerinin üretmiş olduğu bir bilinç söz konusudur. Ancak bayrak renklerinin, futbol takımı renkleri nispetinde değişime fazlaca direnç gösterdiği görülür. Futbol takımı renkleriyle okul üniforması renkleri kıyaslandığında, bu sefer futbol takımı renkleri okul üniforması nipetinde daha muhafazakar bir hale dönüşebilmektedir. Bu noktada örnek vermek 
gerekirse, bir zamanlar Fransız askerinin giydiği kırmızı pantolon çabuk göze çarpmasından dolayı onların savaşlarda daha kolay ölmelerine sebep oluyordu. Yöneticiler bu pantolonların renklerinin değiştirilmesini istediğinde, Fransız generaller kırmızı pantolonu çıkarmamak için direnmişlerdi (Pastoureau 2005: 174-175). Çünkü kırmızı Fransa'da asaletin yegâne temsilcisi olarak algılanmaktaydı. Kırmızı pantolonun kendisini dayandırmış olduğu gerçekçi zemin burada rengin üretmiş olduğu kolektif bilincin de realist yani gerçekçi bir karakterde olduğunu ortaya koymaktadır. Esasen bir rengin oluşturmuş olduğu ortaklık alanı, ne kadar fazla kişi tarafından benimseniyorsa ve ne kadar uzun süredir bir kitlesel temsil olma iradesini taşıyorsa, rengin o denli muhafazakar olduğu görülmektedir. Nihai olarak bu gerçekçi görüntünün kitlelelere en basit tabiriyle; "o kadar kişi, o kadar zamandır bu rengin bu anlamı taşıdığına ikna olmuşsa o zaman bu kesinlikle böyledir" hissiyatını uyandırdığı görülmektedir. Bu realist tavrın, zaman içerisinde gerçekçilikten beslendiği damar vasıtasıyla kutsala dönüşebildiği sıklıkla karşılaşılan bir vakıa olmaktadır. Ancak bu realist görüntü yine toplumsal aktörün habitusuna göre izafi bir hal alabilmektedir.

Zamanla sembolleşmiş olan kimi renklere yönelik yaklaşımlar toplumsal konsensüsten neşet etmiş olabilmekte ve dahası bu tavırlar ahlaki birer öğreti halini alabilmektedirler. Sembolik renklerin ürettiği etik, işlevsel olarak toplumsal düzeni tesis eden ve ortak paydayı gözle görünür kılan bir unsur olarak okunabilir. Bir sembol; belirli bir hikâyenin yaşayan şahidi olduğu kadar, belli bir kitlenin belli hikâyeleri hifzetmesine de sebep olabilir. Sembolün söz konusu hikâye üzerinden bir ortaklık ve belki de bir kardeşlik şuuru tesis etmesi bayrak, başörtüsü, haç, sarık, serpuş, puşi gibi gündelik hayatın hemen her alanında mevcudiyetini sürdüren envanterler üzerinden gözlemlenebilir. $\mathrm{Bu}$ envanterlerden birisi olarak görülebilecek renk, aynı işleve -özellikle ürettiği sembolizma için söylemek gerektiğinde- sahiptir. Bu gibi semboller, bireyin ‘bilişsel evrenini ve kültürel algısını' belirler (Akın 2011: 127-128). Bu bilişsel evren gündelik hayatın bileşenleri olarak addedilebilecek unsurları etkilemekle kalmaz, rüyaların içeriğini bile etkileyebilir (Junk 1964). Özne, rüyasında doğrudan hiçbir toplumsal sınırlayıcılık söz konusu değilken bile, toplumsal bilinç ve toplumsal etkinliklerin öngördüğü sınırlar dâhilinde rüya görebilmektedir. Bir kişinin toplumsal alanda var olan iyilik-kötülük ya da güzellik-çirkinlik algılarının rüyalarda bile yansıması, diğer bir deyişle bireyin genel olarak tanımlı bir etik ve estetik değerlerle donatılmış muhayyile üzerinden rüya görmesi; onun toplumsal bilincinin, kişisel bilincine ve hatta bilinçaltına nasıl nüfuz ettiğinin göstergesi olarak algılanabilecek bir nitelik taşımaktadır.

Burada sembollerin ve görüntülerin esas işlevi hem toplumsal düzene olan etkinin kontrolü hem de yeni anlamların yaratılması süreci olarak ifade edilebilir (Habermas 2001: 9). Nihai olarak sembol ve toplumsal aktör arasındaki ilişki, bir bilinç üzerinden ikame edilmektedir. Bu bilincin her bir parametresini oluşturan bilgi stokları bireye bu bilgilerin başkaları tarafından da kullanıldığı hissini vermektedir. Son kertede gündelik yaşamın etkileşimi, bu bilgi stoklarının telkinleri etrafında gelişmektedir (Erbaş 1984: 162). Her bir rengin ayrı ayrı bürünebildiği sembolik hususiyet ise bu kolektif bilinci inşa eden argümanlardan birisi olarak okunabilir. Esasında kolektif bilincin inşası sürecinde bireylerin kendisine ortaklık alanı olarak belirlediği, din, siyaset, tarih, dil gibi unsurların hemen hepsi kendi içerisinde bir sembolizasyon düzeni ve etiği oluşturmaktadır. Söz gelimi tarihsel sembollerle dini semboller arasındaki yapısal fark ve bu yapısal farkların gündelik hayat içerisinde, bireylerin eyleme biçimlerinde ne denli etkili olduğu meselesi; bir bütün olarak göstergebilimsel manada sembol çözümlemesinin serencamını ortaya koymayı 
gerektirmektedir. Bu sebepten ötürüdür ki ortalama bir bakış açısı sağlamak adına yapılan her bir felsefi ve sosyolojik analiz, genelleme imkânı ortaya koyamasa da din, siyaset ya da sanat gibi farklı alanlardaki sembolizasyon sürecini ortaya koymak açısından önem teşkil etmektedir.

Renklerin üretmiş olduğu kolektif bilinç bir yandan kitlelerin kendisini ifade etmesi adına güçlü bir yön gösterici olurken, diğer yandan da rengin üretmiş olduğu bu bilincin araçsallaştırılması söz konusu olabilir. Başka bir deyişle renk; kimi zaman bir 'bizlik' ve 'benlik' şuurunun sıfırdan inşası için kullanılabilirken, kimi zaman da mevcut olarak inşa edilmiş 'bizlik' ve 'benliğin' ifadesi için zaruri bir önkoşul olabilmektedir. Gökçen'in (2001: 306) protestocu için bayrak ve flamayı bir ontolojik ispat olarak yorumlaması, renkler açısından ifade edilen duruma mesnet oluşturabilir. Nitekim renkler özellikle politik ve dini platformlarda sembolik olarak 'biz de varız! hem de bir kimlik, tarih, şekil, ruh ve renk ile varız' gibi söylemlere temel oluşturan nesnel gerçeklikler olarak karşımıza çıkmaktadır. Bu durum haliyle, rengin kolektif bilinç inşa etme işlevinin yanında özne için bir kimlik ve aidiyet unsuru haline de dönüştüğünü göstermektedir.

Renklerin ürettiği kolektif bilinç, inşa ediliş tarzı ve üslubuna göre bir farklılık arz edebilir. Mesela bayrak renginin ürettiği kolektif bilinç ile bir siyasal parti renginin ürettiği kolektif bilinç arasında bir farklılığın söz konusu olduğu ifade edilmişti. Çünkü siyasal partiler her zaman bir varoluş göstergesi olarak görülmez iken; bayrak, bu durumun tersine bir varoluş göstergesi olarak okunabilmektedir. Bu bakımdan üretilen kolektivite dayandığı tarihsel arka plan bakımından da önem arz etmektedir. Misal vermek gerekirse, önemli bir tarihi mekân isminin bir fetih sonucu değiştirilmesinden duyulan huzursuzluk ve endişe, sembollerin üretmiş olduğu ortaklık alanının dayandığı tarihsel arka planını ve buna mukabil onların muhafazakârlığını ortaya koyması açısından önemli olabilir (Elgenius 2005: 10-11). Esasında uzun süreçler nihayetinde ortaya çıkmış müşterek inançların ve sembollerin karakter olarak kendisine daha reel ve meşru zeminler bulduğu görülmektedir. Bayrak, havra, kilise, minare vs. bunların bir ürünü olarak görülebilir. Öte yandan kısa zamanda üretilip tüketilen müşterek bilinçlilik hallerinin ve sembollerin daha az ömürlü ve etkili olduğu görülmekle beraber, bunların kısa zaman sonra reel karakterini de kaybettiği görülebilmektedir. Söz gelimi sembolik olarak bir siyasal liderin inşa ettiği figür, o siyasal liderin gündemine bağlı olarak kısa zamanda tüketilebilmekte ve unutulabilmektedir. Ancak sembolü üreten kurum ya da kişi, hitap ettiği kitle için taşıdığ sembolü gündelik hayat içerisinde uzun zamanlar var edebilmekte ya da sembol tarihe yenik düşebilmektedir. Haliyle burada sembolü üretenler ve sembolün üretildiği bağlam, söz konusu sembolün etkisini ve tarih içerisindeki yerini belirleyebilmektedir.

Renklerin üretmiş olduğu toplumsal konsensüs, üretildiği toplumda aynı zamanda bir muhafazakârlığa da sebep olabilmektedir. Bunun yanında insanın muhafazakâr düşünce eğilimi eski zamanlarda boyama eğilimine sirayet etmiştir. Eski boyayanlar renklerin doğasını bozmamak adına renkleri birbirine karıştırmamışlardır. Bu durum da renk seçeneklerinin az olmasına sebebiyet vermiştir. Var olan seçenekler ise doğanın insana bahşettiği belirli sınırlılıklar üzerinden teşekkül etmiştir. Sonuç olarak bundan dolayı kimyasal boya üretimi tekniklerinin gelişimi gecikmekle kalmamış, renk karşısında yeniliklerden uzun süre imtina edilmiştir (Pastoureau 2005: 78). Renkler konusunda takınılan muhafazakârlığın altında genel olarak yine etik ve estetik kaygıları ön plana çımmaktadır. Yani boyayanlar ve boyattıranlar kendi döneminin şartlarında, zevksizlik ve 
ahlaksızlıktan duydukları endişeden dolayı renklere karşı muhafazakâr bir tutum sergileyebilmişlerdir.

Kitle iletişim araçlarının yaygınlaşmasıyla beraber artan küresel dinamikler sürekli ve hızlı bir şekilde yeni semboller üretmektedir. Üretilen bu sembollerin ömrünün çok kısa süreli olması, söz konusu sembolün ortaya çıkışındaki gerekçenin ortandan kalkmasıyla veya küresel dünyanın değiştirme hızının sembollere olan etkisiyle açıklanabilecek bir husus gibi görünmektedir. Toplumsal manzara içerisindeki kalıcılık, büyük oranda küreselleşme gibi "iktidar stratejilerine" bağlı kalmaktadır (Lefebvre, 2010c: 103). Buna mukabil görünen o $\mathrm{ki}$, şimdiki zamanlarda gerek sembol noktasında gerekse renk noktasında, eşyaya atfedilen değer, kimi iktidar aygıtlarının² etkisiyle kısa bir süre içerisinde değişim ve dönüşüm geçirmektedir. Bu durumun gözlenebileceği en iyi alanlardan birisi tekstil ve/veya mobilya sanayi olarak karşımıza çıkmaktadır. Bu sektörlerde de modern insanın araçsal aklının sembol ve mevcut imge dünyasına, eskisine oranla artık daha az tahammül edebildiği ve onları sürekli değiştirmek istediği görülebilmektedir. İlaveten burada şaşırtıcı bir noktaya değinmek gerekirse, bilim dünyasından da sembollere karşı yaklaşım 'fayda getirmez öğeler' olarak görülebilmektedir. Mesela modern ulusçuluk teorilerinin çoğuna göre semboller, mit ve efsane dünyasına aittir ve önemi gayet düşüktür (Elgenius 2005: 10). Hâlbuki hangi açıdan düşünülürse düşünülsün semboller müşterek yaşamayı öğrenmenin gerekli materyalleri konumundadır. Semboller, sıradan insanların işini kolaylayabilecek hayati potansiyellere sahipken, bilim insanlarının da insanın nasıl organize olduğunu anlaması açısından önemli bir alanı işgal ederler.

\section{SEMBOLIKK RENGE YAPILAN BİREYSEL YORUM VE DEĞİŞIM}

Rengin yapısal özelliği, verili koşullarda ona sabit ya da benzer anlamların atfedilmesine sebep olmaktadır. Bir eşya olarak renk, belirli bir ontolojik kimlik ile belirli çağrışımları ve anlamları sağlayabilmektedir. Her nasıl ki normatif bir unsurun -mesela dinyapısında ve anlamında zaman içerisinde değişiklikler olabiliyorsa, bunun yanında birey ve normatif unsurlar arasındaki ilişkinin içeriği ve üslubu değişebiliyorsa; renkte de o minvalde birey-renk ilişkisi zemininden bakıldığında anlamsal bir değişikliğin söz konusu olabildiği görülmektedir (Pastoureau 2005 \& 2012). Renk anlamlarının yanında özellikle normatif sistemlerin değişme hızı son iki yüz yılda oldukça yüksek bir ivme kazanmıştır. Baudrillard (2014: 41) renklerdeki bu değişimi "düzende görülen genel bozulmanın bir sonucu" olarak görür. Nitekim insan, binlerce yıldır içinde yaşadığı toplumsal düzenden oldukça uzaklaşmış durumdadır (Giddens 2005: 40). Buna mukabil renklerin sahip olduğu anlamlar da son yıllarda daha hızlı bir şekilde değişim göstermektedir.

Renge atfedilen anlamın değişme ivmesi ve herhangi özgül bir rengin bireyi sosyolojik olarak etkileme gücü, sürekli olarak farklılaşsa da bunun her renk için ve her durum için aynı oranda olmadığı gözlemlenmektedir. Söz gelimi, anlamsal referansını dinden alan bir rengin değişme hızıyla moda ya da sanattan alan bir rengin anlamının değişme hızının aynı olmadığı bilinmektedir. Bu durum haliyle kendisine anlam atfedilen rengin referansının ya da anlamsal kaynağının, birey üzerindeki etkisine bağlı olarak bir değişim hızı ve biçimi öngörmektedir. Birey, herhangi bir anlamsal referans kaynağının telkinlerini ya da sembollerini hayati bir unsur olarak görüyorsa ve bu anlamin korunması gerektiği noktasında hassasiyet sahibiyse; rengin anlamını o minvalde daha yavaş

2 İktidar aygıtlarından kastedilen şey Lefebvre gibi Marksistlerin iktidar aygıtları olarak gördüğü unsurlardır. Basın, medya, eğlence kültürü, moda vs. buna örnek olarak verilebilir.

SEFAD, 2018 (39): 373-388 
değiştirmektedir. Ancak tam tersi durum için söylendiğinde; birey, rengin anlamsal kaynağını gündelik hayatın rutin unsurları arasında görüyorsa ve ona bir hayatiyet atfetmiyorsa, bu rengin anlamının daha çabuk değişebileceği bilinmektedir. Lefebvre (2010c: 158) bu tip değişimleri göstergesel yapıların konjonktür tarafından zorlanması olarak görür. Renk için söylemek gerektiğinde bu konjonktür; moda, zorlayıcı değişkenler vs. olarak görülebilir. Esasında burada zikredilen durumu analiz etmenin en iyi yöntemlerinden biri, farklı periyotlarda çıkmış ya da aynı zaman dilimi içerisinde çıkmış farklı moda dergilerini incelemektir. Moda dergileri incelendiğinde, rengin anlamsal değerinin nasıl çabuk bir şekilde türetilebildiği veya üretilmiş anlamların nasıl çabuk bir şekilde tüketilip yerine başka anlamların ikame edilebildiği rahatlıkla görülecektir. ${ }^{3}$

Moda gibi daha çok modern zamanların ele avuca sığmaz insan arzularının teskini maksadıyla araçsallaştırılan kimi çağdaş sosyolojik organizasyonlar; her ne kadar da sürekli ve hızlı bir değişimin öngördüğü rota üzerinden yol alsa da semboller ona göre daha yavaş değişmektedir. Lefebvre'ye göre (2010a: 301) sembol tükenmez, sınırsız bir olgu ve değer unsurudur. Bu durum sembolün ontolojik olarak varlığına işaret etse de sembolün içeriğinin ve anlamının tüketilmesi-değişebilmesi söz konusu olabilmektedir. Kültürler değiştikçe semboller de değişmektedir. Kültürel değişme noktasında kimi antropologlar kültürün maddi, kimileriyse manevi unsurlarının daha önce değiştiğini iddia etmektedirler (Arslantürk-Amman, 2012: 236). Sembolik renklerin maddi bir kültür öğesi olarak görülebileceği tartışılabilir ama onların imgesel renklere kıyasla daha yavaş bir değişim gösterdiği bilinmektedir. Sembolik rengin anlamındaki değişimin yavaş olması, sembolizasyon sürecinde rengin dışarıdan yorum kabul etmeme özelliğinin bir sonucu olarak görülebilir. Yine toplumsal yapının çeşitli bileşenlerinde de olduğu gibi burada özne ile yapı arasındaki ilişkinin boyutuna bağlı olarak yavaş veya hızlı bir değişim söz konusudur. Renklerin yapısal mahiyeti göz önünde bulundurulduğunda tıpkı herhangi bir normatif değer gibi kendisini dışarıya kapattığı görülmektedir. Söz gelimi aile içi kuralları sorgulamaya kalkan bir çocuğun karşılaşacağı anne, baba, el âlem gibi engelleyici unsular; nasıl ki bir düzenin öngördüğü müdahale etme biçimlerini içeriyorsa, sembolleştirilen renklere karşı yapılacak sorgulamaların ve karşılaşılacak engellerin, o minvalde aynı sebeplerden olduğu düşünülebilir.

Amerikan sosyoloji geleneğinin genel karakterine bakıldığında toplumsal değişme, kişilerin ya da grupların davranış biçimleri üzerinden okunmaya çalışılmaktadır (Tolan 2005: 278). Gerçekten de yapısal değişimin serencamına bakıldığında, bir yandan bireyin tutum ve davranışları değişirken, diğer yandan bu tutum ve davranışın yansımaları yapı düzeyinde de görülebilmektedir. Pastoureau'nun da defaatle ifade ettiği gibi (2005 \& 2012) renk algılarının değişimlerinde bireysel ve grupsal analizler yapılabilir. Renkler özelde bireysel müdahalelerin sonucu olmak kaydiyla genel olarak herhangi bir kurumun fetvanın ya da 'oradaki bireyden' müstakil olarak algılanabilcek bir başka yapı unsurunun müdahalesiyle de anlamsal bir değişikliğe uğrayabilmektedir. Ancak sembol mesabesinde olan bir rengin, anlamsal değişimi, imgesel renklere kıyasla daha basit olmamaktadır. Çünkü sembollerin dışardan müdahaleyi engelleyecek çeşitli yaptırım gücüne çoğu zaman sahip olduğu görülmektedir. Bunun içindir ki sembolik renge olan müdahelelerin sınırı, onların topluma mal olma özelliğinin yanında çoğu zaman mistik bir kalkanla kendisini koruma altına almasından kaynaklanmaktadır.

${ }^{3}$ Karşılaştırmalar için Bkz. Elle ve Vogue dergilerinin aynı yıllardaki sayılarda işaret ettikleri renk trendlerine ve anlamlarına. 


\section{SONUÇ}

İnsanoğlunun gündelik yaşamda kullandığı sembollere dair yapılan soruşturmada göstergebilimsel manada renklerin önemli bir yeri vardır. Bu mivalde renkler, hem sembol olarak iletişim ve etkileşimin tesis edilmesinde hem de insan imgesinin oluşmasında önemli bir payeye sahiptirler. Sembolik renk anlamlarının oluşmasında bir dizi tarihsel ve mitsel hadiselerin çoğu zaman etki edebildiği bilinirken oluşan anlamların kimi zaman nominalist bir karakter kazanabileceği görülmüştür. Öte yandan bu semboller dayanmış olduğu hikayenin sadece bir temsilcisi değil aynı zamanda hikayenin bir taşıyıcısı hükmündedir. Böylece belirli anlatılar ve öğretilerin nesilden nesile aktarıcıllğını yapan semboller, kendisini realist bilgi felsefesinin argümanları doğrultusunda üretebilmekte hatta söz konusu renk anlamları tarihselliğinden doğan bir meşruiyet ile kitlelelere ya da felsefeye gerçekçi bir anlam hüviyeti sağlayabilmektedir. Yani renk sembollerine yüklenen anlamların uzun bir tarisel arkaplanının oluşu, insanların doğal olarak anlamları olduğu gibi kabullenişne neden olmaktadır. Bu minvalde kimi toplumsal aktörler renklere yüklenen anlamları normatif bir değer addedip, gündelik yaşamda kullandığı imge ve eşyayı bu normatif renk anlamları üzerinden şekillendirmektedir, kullanmanmaktadır.

Sembol anlamlarının tarihsel veya mitsel hadiseler sonucunda doğuşuyla beraber, söz konusu sembol anlamlarının dayandığı realist arkaplan sembollerin şeyleşmesine neden olmaktadır. Şeyleşen semboller dışsal bir hüviyet halini aldıktan sonra, kitlelerin anlam haritalarının belirli parametrelerini oluşturmaktadır. Renkler aynı sembolizasyon sürecine dahil olmalarından dolayı, renk anlamları şeyleşmekte ve hatta belirli renk anlamları, belirli toplumların, belirli öğretiler etrafında aynı anlam haritasını paylaşmasına hizmet etmektedir. Renklerin sembolik anlamlarının, kitleler tarafından ortak olarak benimsenmiş olması, insanoğlunun eşyaya dair geliştirdiği ortak imgenin toplumsal düzenin inşa edilmesindeki rolünü ortaya koymaktadır.

Renk sembollerine nispet edilen anlamların tarihsel süreç içerisinde sürekli olarak değiştiği görülmüştür. Hem sembollere yüklenen anlamların değişmesi hem de sembollerin oluşturmuş olduğu imgelerin değişmesi, insanın değişme ve değiştirme temayüllerinin renkler üzerinden okunabilmesine imkan doğurmuştur. Bu noktada toplumsal değişimin temel dinamiği mesabesinde olan bireysel yorumlar, renk anlamlarının değişimine de zemin hazırlayan hususlar olarak karşımıza çıkmıştır. Buradan sosyoloji literatüründeki yapısalcılık, yapısal işlevselcilik veya post-yapısalcılık anlayışlarının renk değişimlerini açılayacak nitelikte olduğu sonucu çıkmıştır. Kendi ekseninde bir anlamsal yapı oluşturan renkler, tıpkı yapı-fail diyalektiğinde söz konusu olduğu gibi bireyleri etkileyebilmekte ya da onlardan etkilenebilmektedir. Post-yapısalcı analizin "yapı" kavramını toplumsal yapının ötesine taşıyıp, onu göstergesel yapılarla veya dilsel sistemlerle izhar etmesi; birey-renk ilişkisinin değişkenliğinin de en azından sosyal teori kapsamında açıklanabilecek nitelikte olduğunu göstermiştir.

Renklere atfedilen anlamların değişmesi bir kültürün oluşum ve değişim sürecindeki itkilere bağlı bir şekilde gerçekleşmektedir. Bu noktada Çin'deki anlamsal hale ile Almanya'daki anlamsal hale, üretilmiş olan kültürün farklılığından dolayı değişebilmektedir ya da üretilmiş olan kültürler bu haleyi değiştirebilmektedir. Burada kültür ve anlam atfetme etkinliğinin, birbirini şekillendirmek noktasında dikotomik olarak düşünülmemesi gerekmektedir. Bu süreç diyalektik bir süreçtir. Mesela Türk kültüründe kırmızı çoğu zaman güzellik ve estetik bir zemin üzerinden anlamlandırılır. Kırmızıya atfedilen anlamların Türk kültüründen mi kaynaklandığı, yoksa Türk kültürünü var eden 
şeylerden sadece birisinin kırmızıya dair atfedilen anlam mı olduğu tartışması, dikotomik bir çıkmaza neden olabilir. Böylece bu süreci diyalektik olarak kabul etmek, renk ve kültür ilişkisinin anlaşılması için daha elverişli görünmektedir. Siyah, beyaz, sarı, kırmızı vs. bütün renkler toplumların kendi anlam haritalarının ve kültürlerinin uzantısı olarak farklı farklı anlamları refere edebilmektedirler. Ancak aynı zamanda bu anlamların oluşturmuş olduğu sembolik kümeler, kültürleri var edebilmekte, dahası bir kültürü diğerinden ayırt edebilmektedir.

Sonuç olarak denilebilir ki, sembolik renklere atfedilen anlamlar, her kültürün kendi pozisyonuna ve sürecine bağlı olarak oluşmaktadır. Sembollerdeki farklılıkların o kültürün kendi özel şartlarından kaynaklandığı; sembollerdeki toplumlararası benzerliklerin ise o toplumun kültürünün bir başka kültür ile etkileşim sürecinde ortaya çıktığı bilinmektedir. Bu noktada semboller hem bir milletin kendi özel şartlarıla tecrübe ettiği hikâyelerden neşet edebilmekte hem de bir başka ulusun hikâyesi ile hemhal olmuş ama sonradan evrenselleşme temayülü göstermiş hadiselerden etkilenebilmektedir. Sembollerin bu oluşum ve etkileşim süreci sadece renk sembollerinde değil, toplumsal alanda var olan bütün sembollerde benzer bir yaklaşımla çözümlenebilecek düzeydedir. Dine dair kimi sembollerin bile değişkenlik arz edebilmesi, bu süreci daha anlaşılır kılması bakımından önemlidir. Din fenomeninin genel olarak belirli sabiteler üzerine bir anlamsal bütünlük oluşturmasının karşısında, dini sembollerin toplumdan topluma değişkenlik gösterebilmesi; sembollerin oluşum sürecinde kültürün etkisini ortaya koymaktadır. Mesela, din kurumuna bağlllı̆̆ın bir göstergesi olarak ifade edilen tesettür, sarık veya sakal şekillerinin bir sembol olarak toplumdan topluma değişkenlik arz edebilmesi, temel olarak kültürel süreçlerin sembollere olan müdahalesi ile açılanabilecek niteliktedir.

\section{SUMMARY}

In this study, an attempt was made to develop an understanding of the process of symbolic formation of colors and how these symbols are used in the social field. It is emphasized that some of the stories and narratives that lead to the emergence of symbolic meanings are also influential in the formation of color meanings. Thus, it is necessary to resort to the philosophy of knowledge in order to test the meaning of the symbolic color, which is based on the story and the narratives, at the point of correctness of knowledge. In the philosophy of knowledge, it has been seen that nominalist and realist concepts are in need of each other to explain the symbols that conceptually settle into the human mind. The colors that serve to realize the human interaction as both concept and image and as symbols and objects, revealed the effects of the form of mankind's organization of the things and mind. In addition, a reverse reading has been made to understand how the mind and the thing affect man's organization. This dialectic process has been seen to be similar to previous dichotomies of sociological studies. Colors affect both human behavior and are influenced by this behavior in turn. This situation emerges as a dichotomy in the historical process. Thus, this study required the structuralist, structural functionalist, or poststructuralist claims to be taken into consideration in the sociology literature in terms of discourse. When reference is made to sociological theories, it has been shown that colors can affect individual acts in a linguistic and semiotic order specific to itself. The symbolic realization of these effects can transform individual behaviors into collective behaviors. The fact that individuals belonging to similar social reality have the same meaning in some colors reveals the conception of human mind about mind and object. 
The symbols are generally based on a story, and the historical background of the story can change its relevance to the symbols. How long the story is and how many people internalize it can turn the collective consciousness into a realistic one. Thus, when individuals think that the story is a piece of information that is trusted by others, the credibility of the story increases for them. Here the individuals are acting with the understanding that "if so many people are convinced that this color carries this meaning, then this is certainly the case". The collective consciousness produced by the color symbols may seem realistic to the extent of the community to which it is embraced. According to the numerical majority of the society, the meanings of colors are more prone to stay constant and they have resistance against change. The flag, soccer team or school uniform of colors may not be very suitable for changing. In fact, when they are attempted to be changed, this can be opposed by social actors, by taking advantage of the nobility, historicity, aesthetics, or some other characteristic of colors. At this point, for example, flag colors can be more stable than football team colors and football team colors can be more stable than school uniforms. Because those who adopt the flag color have more numerical superiority than those who adopt the soccer team color according to the colors of the football uniform.

Approaches to color symbols can be influenced by ethical reasons, because there is a moral assessment of the generalities of symbols. Symbolic colors can also insist on their meanings at this point with moral justifications. Because, in a society, the violation of symbols or the insignificance can be perceived as a rebellion against the basic values of that society. At this point, it can be perceived as a moral duty for Christians to value white, for Muslims green, and for Turks red in their national flag. Besides, some colors are seen to belong to certain social classes, the prohibition of the use of these colors by others is observed in many societies due to moral reasons. In addition to the ethical field of interest in colors, aesthetics can also display an important understandin of color evaluations. Aesthetic reasons, however, are less effective for the purposes of the symbols. The aesthetic evaluations made about the colors are more subjective and imaginative. It can be said that the meanings attributed by aesthetic values can be discussed within a broader boundary. 


\section{KAYNAKÇA}

Akın, Mahmut Hakkı (2011). Toplumsallaşma Sözlüğü. Konya: Çizgi Kitabevi.

Al-Adaileh, Bilal A. (2012). The Connotations of Arabic Colour Terms. Jordan: Al-Hussein Bin Talal University.

Albayrak, Kadir (2008). "Millî Dinlerde Renk Fenomeni". Çukurova Üniversitesi İlahiyat Fakültesi Dergisi 8 (1): 1-41.

Amsteus, Martin-Al-Shaaban, Sarah vd. (2015). "Colors in Marketing: A Study of Color Associations and Context (in) Dependence". International Journal of Business and Social Science 6 (3): 32-45.

Aydın, Mustafa (2013). Güncel Kültürde Temel Kavramlar. İstanbul: Açlımkitap.

Baudrillard, Jean (2014). Nesneler Sistemi. çev. Oğuz Adanır, Aslı Karamollaoğlu. İstanbul: Boğaziçi Üniversitesi Yay.

Becker, Howard S. (2016). Toplumu Anlatmak. çev. Şerif Geniş, Ebru Arıcan ve Mesut Hazır. Ankara: Heretik Yayıncilık.

Davidson, Arnold Ira. (2002). Arkeoloji, Genoloji. Etik. Faucault ve Bilginin Arkeolojisi. ed. Veli Urhan. çev. Veli Urhan. İstanbul: Paradigma Yayınları. 101-118.

Elgenius, Gabriella (2005). Expressinons of Nationhood: National Symbols and Ceremonies in Contemporary Europe. London: University of London.

Faucault, Michel (2007). Cinselliğin Tarihi. çev. Hülya Uğur Tanrı̈ver. İstanbul: Ayrıntı Yay.

Giddens, Anthony (2005). Sosyoloji. çev. Cemal Güzel. Ankara: Ayraç Yayınevi.

Gökçen, Ahmet (2001). Protestocu: Kimlik, Arkaplan ve Araçlar. ed. Mehmet Ali Aydemir. İstanbul: Açılımkitap. 299-314.

Junk, Carl G. (1964). Man and him Symbols. Spain: Anchor Press.

Lefebvre, Henri (2010a). Gündelik Hayatın Eleştirisi I. çev. Işık Ergüden. İstanbul: Sel Yayıncilik.

Lefebvre, Henri (2010b). Gündelik Hayatın Eleştirisi II Gündelik Hayat Sosyolojisinin Temelleri. çev. Işık Ergüden. İstanbul: Sel Yayıncılık.

Lefebvre, Henri (2010c). Gündelik Hayatın Eleştirisi III ModernitedenModernizme (Gündelik Hayatın Meta-Felsefesi). çev. Işık Ergüden. İstanbul: Sel Yayıncılık.

Pastoureau, Michel (2005). Mavi Bir Rengin Tarihi. çev. İnci Malak Uysal. Ankara: İmge Kitabevi.

Pastoureau, Michel (2012). Siyah Bir Rengin Tarihi. çev. Mesut Tufan. İstanbul: Sel Yayıncllık.

Reisman, David (2016). Yalnız Kalabalık Amerikan Toplumsal Karakterinin Değişimi Üzerine Bir İnceleme. çev. Yeşim Erdem. Ankara: Heretik Basın Yayım.

Ritzer, George (2013). Modern Sosyoloji Kuramları. çev. Himmet Hülür. Ankara: De Ki Basım Yayım.

Ritzer, George-Stepnısky, Jeffrey (2014). Sosyoloji Kuramları. çev. Himmet Hülür. Ankara: De Ki Basım Yayım.

Shaviro, Steven (2009). Without Criteria: Kant, Whitehead, Deleuze, and Aesthetics, Steven Shaviro. London: The MIT Press.

Tokdil, Ezgi (2016). Renk Kuramları ve Andre Lhote Örnekleminde Renk Algısına Fenomenoloji Yaklaşım. İdil 5 (22): 547-568.

Tolan, Barlas (2005). Sosyoloji. Ankara: Gazi Kitabevi .

Weber, Max (2008). Sosyoloji Yazıları. (Düzenleyen H. H. Gerth, C. W. Mills). çev. Taha Parla. İstanbul: Deniz Yay.

Wittgenstein, Ludwig. (2007). Renkler Üzerine notlar. çev. Ahmet Sarı. Ankara: Salkımsöğüt Yay.

Yu, Hui-Chih (2014). A Cross-Cultural Analysis of Symbolic Meanings of Color. Chang Gung Journal of Humanities and Social Sciences 7 (1): 49-74. 